\title{
O desenvolvimento do setor siderúrgico brasileiro entre 1900 e 1940: Crescimento e substituição de importações
}

\author{
Gustavo Barros \\ Professor - Universidade Federal de Juiz de Fora - Faculdade de Economia \\ Endereço: Campus Universitário s/n, Bairro Martelos - Juiz de Fora/MG - Brasil \\ CEP: 36036-330 - E-mail: gustavo.barros@ufjf.edu.br - http://gustavo.barros.nom.br/
}

Recebido em 14 de dezembro de 2013. Aceito em 19 de março de 2014.

\begin{abstract}
Resumo
No início do século $X X$, o setor siderúrgico brasileiro tinha muito pouca expressão prática. Contudo, quando a Companhia Siderúrgica Nacional foi criada, em 1941, como uma resposta ao problema siderúrgico nacional, o setor siderúrgico doméstico já era bem mais significativo. De fato, entre 1900 e 1940, e sobretudo nas décadas de 1920 e 1930, o setor siderúrgico brasileiro foi capaz de conduzir um importante processo de desenvolvimento. A reconstrução desse processo de evolução setorial, centrado no processo global de crescimento da produção siderúrgica, na sua composição e na substituição de importações que o setor foi capaz de realizar, é o objeto deste trabaIho. Além disso, o artigo faz uma avaliação crítica dos dados quantitativos disponíveis sobre o setor no período, complementando-os e os expandindo, e procura fazer um uso analítico mais sistemático deles.
\end{abstract}

\section{Palavras-Chave}

Siderurgia. Desenvolvimento setorial. Indústria. História econômica.

\begin{abstract}
In the early 20th century, the Brazilian steel-making sector had very little practical meaning. However, when the Companhia Siderúrgica Nacional (National Steel Company) was created in 1941, as an answer to the national steel problem, the domestic steel-making industry was much more significant. Indeed, between 1900 and 1940, and especially in the 1920s and 1930s, the Brazilian steel-making sector was able to achieve an important development process. The reconstruction of this process of industrial evolution, centered on the aggregate growth of steel production, on its composition, and on the import substitution it was capable of engendering is the object of this work. Furthermore, the paper evaluates critically the quantitative data available for the sector in the period, complementing and expanding them, and seeks to make a more systematic analytical use of them.
\end{abstract}

- Este trabalho foi realizado com apoio do CNPq, Conselho Nacional de Desenvolvimento Científico e Tecnológico, Brasil, e do DAAD, Serviço Alemão de Intercâmbio Acadêmico. Agradeço os comentários recebidos de Flávio Saes, Renato Colistete, Alexandre Macchione Saes, Renato Leite Marcondes, Otávio Soares Dulci, Marcelo Magalhães Godoy, dos participantes do 4lo Encontro Nacional de Economia da ANPEC, do XVI Seminário sobre a Economia Mineira (Diamantina) e do VII Encontro de Pós-Graduação em História Econômica \& $5^{\mathrm{a}}$ Conferência Internacional de História Econômica, bem como de um parecerista anônimo. 


\section{Keywords}

Steel-making. Brazilian Steel industry development. Economic History.

JEL Classification

N66. O14.

\section{Introdução}

O Brasil entrou no século XX com um setor produtor de ferro e aço de significado prático muito reduzido. Já a partir de 1910, ganhou corpo o debate sobre o problema siderúrgico nacional em torno de alguns projetos que vinculavam a produção siderúrgica no país com os projetos então surgidos para a exportação de minério de ferro da zona ferrífera de Minas Gerais. As dificuldades de abastecimento enfrentadas pela economia brasileira pouco depois, durante a Primeira Guerra, acentuaram a percepção da importância do problema tanto por autoridades governamentais quanto por empresários brasileiros. Esse debate foi bastante intenso e durou mais de três décadas. O problema siderúrgico só seria dado por resolvido com a criação da Companhia Siderúrgica Nacional (CSN), em 1941, e a construção da usina de Volta Redonda, inaugurada em 1946.

Os impasses resultantes desse debate, centrado em grandes projetos siderúrgicos vinculados à exportação de minério de ferro, e o destaque recebido por ele na historiografia, poderiam fazer crer que o problema siderúrgico permaneceu intocado ao longo de todo o período. ${ }^{1}$ Mas não foi este o caso. Enquanto se desenrolava o debate, o setor siderúrgico brasileiro foi capaz de conduzir um importante processo de desenvolvimento e já possuía, em 1941, uma dimensão bem mais significativa do que aquela com que entrara o século. O país já contava então com um bom número de empresas dedicadas à produção siderúrgica, que também já se diversificara razoavelmente ao longo do período. Enquanto em 1900, o país podia produzir apenas quantidades relativamente pequenas de ferro-gusa e de ferro maleável por processos diretos, em 1941, já produzia praticamente

${ }^{1}$ Os principais trabalhos na historiografia que tratam da questão siderúrgica nesse período, incluindo aí tanto o debate em torno do chamado "problema siderúrgico nacional" quanto o desenvolvimento do setor, são Silva (1972); Baer (1969, 1970); Martins (1976); Wirth (1970); Bastos (1959); Rady (1973); Gomes (1983); Felicíssimo Jr. (1969); Peláez (1972); Barros (2011, 2013). 
todo o ferro-gusa, uma grande parte do aço e uma parte não desprezível dos laminados demandados internamente.

Contudo, a historiografia sobre o setor siderúrgico brasileiro, ainda que não sem motivo, esteve fortemente marcada pela figura proeminente da CSN. E, com isso, ela absorveu boa parte do discurso que, à época, visava legitimar a criação da nova estatal, e que, por isso mesmo, depreciava o setor preexistente. Paradigmática dessa crítica contemporânea ao setor siderúrgico existente naquele momento foi a chamada "entrevista de São Lourenço", concedida por Getúlio Vargas, em abril de 1938. Então em plena campanha em favor da "grande siderurgia", ele atacava pesadamente o setor existente e afirmava, entre outras coisas, que "a nossa produção siderúrgica atual é reduzida, cara e anti-econômica [...]". ${ }^{2}$ Podemos entender que Vargas sentisse a necessidade de fazê-lo para legitimar o projeto então em discussão e que, alguns anos mais tarde, viria a ser a CSN. Menos justificável é a absorção a posteriori desse discurso, de maneira pouco mediada, pela historiografia. Isso se deu, na prática, pelo reconhecimento tácito praticamente universal pela historiografia da existência de uma superioridade absoluta da "grande siderurgia" a siderurgia feita em grande escala, com carvão mineral - sobre a "pequena siderurgia" - a siderurgia em escala pequena ou média, realizada com carvão vegetal - que era a siderurgia existente no país antes da CSN. ${ }^{3}$ Esse era um argumento, em princípio técnico, fartamente utilizado à época nos debates. Se é certo que ele tinha fundamento, pois a produção em escala maior com carvão mineral seria efetivamente capaz de produzir a custos unitários relativamente mais baixos, ele não deixou de ser utilizado de forma instrumental pelos debatedores contemporâneos. Contudo, a mera existência de uma tecnologia relativamente superior não impediu o setor que se desenvolveu no país de ocupar o seu espaço no mercado doméstico, nas condições então vigentes. ${ }^{4}$

2 Vargas (1938: 179).

3 Se esse reconhecimento tácito é bastante geral, ele não deixa de encontrar formulações mais explícitas (veja, por exemplo, Martins, 1976: 175, 177-78, 193-94, 198, cap. 5, passim; Bastos, 1959: 157-58; Peláez, 1972, cap. 4, passim; Rady, 1973: 116-19). Uma exceção a esse respeito é Gomes (1983) que, talvez por ser mineiro, adota perspectiva mais favorável ao setor siderúrgico desse período.

${ }^{4}$ Importante observar a esse respeito também que, uma vez que a CSN entrou no mercado, a partir da segunda metade da década de 1940, o resultado não foi uma canibalização do setor preexistente pela nova e mais eficiente companhia. Ao contrário, a tomar pela evolução das participações das empresas na produção nacional na década seguinte, o que se deu esteve bem mais próximo de um convívio amigável e de uma partilha do mercado doméstico. 
Assim, como teremos ocasião de observar ao longo deste artigo, embora o setor siderúrgico brasileiro anterior à criação da CSN tivesse limitações concretas e significativas, as realizações de que foi capaz nas décadas de 1920 e 1930 tampouco podem ser desprezadas.

Essa evolução setorial será o nosso objeto de estudo neste artigo, que analisará, em particular, o processo global de crescimento da produção siderúrgica, a sua composição, bem como a substituição de importações que o setor foi capaz de realizar. Nesse sentido, pretendemos dar aqui uma visão panorâmica desse processo de desenvolvimento, focando nessas dimensões agregadas e em algumas características estruturais do setor. Para tanto, faremos uso de extensivo conjunto de dados sobre o setor siderúrgico brasileiro no período, ${ }^{5}$ além de informações qualitativas, na medida do necessário.

Este artigo está organizado em mais quatro seções, além desta introdução. Na seção 2, faremos uma discussão sobre os dados disponíveis para o setor no período em estudo, suas limitações e sobre o que fizemos aqui para mitigá-las. Na seção 3 , trataremos da evolução da produção do setor, incluindo o seu crescimento quantitativo, bem como a sua composição, procurando compreender certos aspectos qualitativos do desenvolvimento do setor através dela. Na seção 4, acompanharemos o comportamento dos coeficientes de importação para produtos siderúrgicos no país, o que nos permite avaliar, numa escala adequada, os avanços do setor ao longo do período. Por fim, na seção 5 , tecemos algumas considerações finais.

\section{Dados disponíveis sobre o setor siderúrgico brasileiro entre 1900 e 1940}

A dimensão quantitativa da evolução do setor siderúrgico brasileiro durante o período em estudo não deixou de ser objeto da historiografia. Ao contrário. ${ }^{6}$ De fato, temos dados até relativamente detalhados

\footnotetext{
5 Apêndice estatístico em Barros (2011). Os dados utilizados mais intensivamente aqui constam nas Tabelas A-1 a A-3, anexas.

6 Dentre os trabalhos citados na nota 1 destacam-se pelo tratamento mais detalhado do desenvolvimento setorial Baer (1969); Silva (1972); Barros (2011, 2013). Até mais recentemente, o trabalho que mais sistematicamente havia examinado os dados quantitativos disponíveis sobre o setor siderúrgico brasileiro no período era o de Baer (1969).
} 
sobre a produção siderúrgica nesse período. Contudo, pouca discussão se fez em torno da qualidade, da completude e da confiabilidade dos dados disponíveis.

Concretamente, a historiografia sobre o assunto conta, direta ou indiretamente, praticamente com uma fonte primária única desses dados, que são os levantamentos feitos ao longo da década de 1930 pelo Ministério da Agricultura. Esses levantamentos foram publicados em duas ocasiões pelo Ministério, sob a organização de Alpheu Diniz Gonsalves. ${ }^{7}$ E tinham como origem a concessão de favores às empresas do setor siderúrgico que haviam sido feitas ao longo da década de 1920 e que tinham como contrapartida que as empresas beneficiadas facultassem ao governo certo grau de monitoramento. ${ }^{8}$ Esses decretos não foram prorrogados nem aplicados depois de 1926, porém, as obrigações envolvidas permaneciam enquanto perdurassem os favores concedidos às empresas que os haviam obtido. Ao que tudo indica, os dados disponíveis para a década de 1920 ou anteriores foram levantados retroativamente, já que os dados publicados em 1937 são mais completos que os publicados em 1932 para esse período. Isso tem como implicação a inclusão implícita de algumas estimativas, mas que são apresentadas pelo Ministério como dados. ${ }^{9}$

Além disso, as publicações dos dados pelo Ministério eram pouco rigorosas na distinção entre dados faltantes ou dados sabidamente inexistentes. ${ }^{10}$ Ao contrário, declaravam explicitamente tratar-se de dados "desde o início do funcionamento das usinas". "Diante disso, e sem maiores discussões, a historiografia incorporou esses dados como completos.

7 Gonsalves $(1932,1937)$. Outra fonte primária coeva relevante de dados sobre o setor que, muito provavelmente, tinha por base os mesmos dados do Ministério da Agricultura é Jobim (1941).

8 Trata-se, sobretudo, dos decretos $n^{0} 12.944$ de 30/mar/1918, no 4.246 de 6/jan/1921 e $n^{\circ}$ 4.801 de $9 /$ jan/1924.

9 Essa última afirmação vale sobretudo para os dados de valor da produção. Por exemplo, o preço implícito da tonelada de ferro-gusa para cada empresa individualmente, e para todas elas, entre os anos de 1915 e 1922 é de exatos 230 mil-réis. Já o preço implícito da tonelada de aço para cada empresa entre 1925 e 1933 é de redondos 450 mil-réis. Esse tipo de regularidade seria difícil de imaginar se se tratassem de dados realizados, e não de estimativas.

10 Ambos igualmente referidos nas tabelas pelo mesmo traço "-".

11 Gonsalves (1937: 78-80). 
Contudo, é fácil verificar que eles possuem lacunas diversas, de maior ou menor relevância. De fato, a maior parte das empresas siderúrgicas mais relevantes operando no período pleitearam e obtiveram os favores previstos nos decretos da década de 1920, mas nem todas. Houve dois tipos de exceção a essa regra. Primeiro, as empresas pequenas, que ficavam de fora dos termos do decreto, por não atingirem a produção mínima requerida. E, de fato, temos notícia por outras fontes de um número de empresas pequenas que operaram durante o período, mas que não constam nos dados do Ministério da Agricultura. Em segundo lugar, ficou também de fora dessa onda de concessões de favores a maior empresa siderúrgica brasileira até meados da década de 1920 e que permaneceu sendo uma das maiores na década seguinte, a Companhia Brasileira de Mineração e Metalurgia. ${ }^{12}$

Por esse motivo, essa que era uma das principais empresas do país nem sempre forneceu os dados ao Ministério da Agricultura e, quando o fez, tampouco o fazia de maneira completa. ${ }^{13}$ Assim como tampouco o fizeram muitas das usinas menores, que não se enquadraram nos decretos. Outra lacuna dos dados diz respeito à Queiroz Jr., ${ }^{14}$ que operava desde 1898-9, mas cujos dados são apresentados pelo Ministério apenas a partir de 1915. Por fim, ao que tudo indica, a Hime \& Cia. produziu laminados leves entre 1918 e 1925, ${ }^{15}$ antes da criação, por ela, da Cia. Brasileira de Usinas Metalúrgicas, em 1926, dados estes que tampouco constam nas publicações do Ministério. Acredito, porém, que do ponto de vista do nosso objetivo neste artigo, as lacunas mais importantes sejam as referentes à Cia. Brasileira de Mineração e Metalurgia. Os dados faltantes para esta empresa estão localizados em dois períodos: i) entre 1918 e 1925, quando a

12 Pouco se notou e menos ainda se discutiu esse fato. Foge ao escopo deste artigo a questão do porquê a Cia. Brasileira de Mineração e Metalurgia teria sido excluída desses favores, mas posso sugerir que se trataram fundamentalmente de motivos políticos. Formalmente, a empresa foi excluída dos termos dos decretos por uma regulamentação tardia (decreto 17.091 de 21/out/1925) que determinava que o requisito de produção mínima deveria ser especificamente de ferro-gusa. A companhia era a única de maior porte que não se dedicava a essa etapa produtiva, realizando apenas o refino (produção de aço) e a laminação.

13 Por exemplo, Gonsalves (1937) apresentava dados recentes das diversas empresas operando no país. No caso da Cia. Brasileira de Mineração e Metalurgia, consta explicitamente que a empresa se recusou a fornecer dados de produção e de custo. Limitou-se a fornecer o montante de impostos pagos no exercício de 1934 e a anotar que "Até a presente data não gosamos de quaesquer favores concedidos pelos poderes publicos." (Gonsalves, 1937: 85).

14 Anteriormente Usina Esperança.

15 Temos relatos de que a Hime \& Cia. iniciou a produção de laminados leves durante a Primeira Guerra, assim, podemos presumir que ela continuou essa operação nesse período antes de finalmente criar uma empresa dedicada à produção siderúrgica. 
antecessora da companhia, a Companhia Mecânica e Importadora operou produzindo aço e laminados; ii) durante a crise, entre 1930 e 1932, quando faltam dados de produção da companhia e subentendeu-se até o momento que a companhia teria deixado de operar durante esses anos por conta da crise, mas temos disponíveis outras informações que nos indicam que esta hipótese não procede. $\mathrm{Na}$ medida em que os dados foram tratados pela historiografia como completos, isso trouxe consequências para o entendimento que se tem do crescimento do setor nos anos 1920 e para a avaliação do impacto da crise do início dos anos 1930 sobre o setor. Ora, não é difícil compreender a relevância da falta dos dados entre 1930 e 1932 de uma empresa que, em 1929, representava mais de $17 \%$ do valor da produção nacional.

Contudo, existem algumas outras fontes que nos permitem complementar esses dados, e preencher algumas dessas lacunas, mas certamente não todas. Alguns dados esparsos de produção de pequenas empresas puderam ser encontrados. Dados do consumo de sucata pela Cia. Brasileira de Mineração e Metalurgia entre 1930 e 1932 constam do relatório final de 1933 da Comissão Nacional de Siderurgia, o que, em primeiro lugar, nos dá segurança em afirmar que a empresa esteve operando nesses anos e, em segundo lugar, nos permite fazer uma estimativa sobre os seus volumes de produção. ${ }^{16}$ Por fim, dados de produção da Queiroz Jr. anteriores a 1915 também puderam ser encontrados em outras fontes. ${ }^{17}$ Permanecem como lacunas nos dados de produção, os anos da Cia Mecânica e Importadora e da Hime \& Cia., entre 1918 e 1925, que antecederam a criação por estas da Cia. Brasileira de Mineração e Metalurgia e da Cia. Brasileira de Usinas Metalúrgicas, bem como os dados de outras empresas de menor porte.

Os dados de produção utilizados nesse trabalho, portanto, têm por base aqueles coletados pelo Ministério da Agricultura, mas complementados onde foi possível fazê-lo através de outras fontes. Além desses dados, fazemos uso, neste artigo, de dados de importação para o cálculo de coeficientes de importação. Werner Baer já havia feito estimativas de coeficientes de importação para ferro-gusa, aço e laminados, a partir de $1915 .{ }^{18}$ Para tanto, porém, fazia uso de dados secundários da FGV, agregados por grupo de produtos (ferro-gusa,

\footnotetext{
${ }^{16}$ BSGM, no 75, 1935, p. 130.

${ }_{17}$ Carvalho (1919: 173).

${ }^{18}$ Baer (1969: 61, 85).
} 
aço e laminados), sem uma discussão sobre se havia efetivamente adequada comparabilidade entre o que estava sendo incluído em cada uma das categorias nas séries de produção e de importação. ${ }^{19}$ Para contornar esse problema, e para estender essa série para trás, desde 1901, remetemos aqui diretamente aos dados primários desagregados de comércio exterior do Brasil, com base nos quais preparamos as séries de importação que utilizamos para calcular os coeficientes de importação. ${ }^{20}$ Além disso, essa nova série de importações também nos permitiu calcular séries para o coeficiente de importações em valor, previamente indisponíveis, possibilitando-nos acompanhar em alguma medida aspectos qualitativos da substituição que ocorreu dentro de cada categoria durante o período.

Por fim, ainda sobre os dados utilizados nas análises que se seguem, vale mencionar a tentativa de construir um indicador agregado do crescimento da produção para o setor siderúrgico como um todo. Algo que, na verdade, estava indisponível na historiografia em função de determinadas características do setor siderúrgico, pois este setor produz, essencialmente, três tipos de produtos: ferro-gusa, aço e laminados. Contudo, ao mesmo tempo em que cada um desses três produtos pode ser vendido para outros setores da economia, ${ }^{21}$ os dois primeiros são também os principais insumos da própria produção siderúrgica. De forma que dispomos, na prática de três séries de produção siderúrgica, uma para cada um desses produtos, mas que não contemplam o consumo do próprio setor siderúrgico de produtos siderúrgicos como insumos. Procuramos aqui, explorando informações qualitativas e quantitativas de cada uma das empresas individuais atuando no setor, estimar o autoconsumo de seus próprios produtos, de forma a conseguir obter uma série agregada que procura medir o quanto da produção siderúrgica no país destinava-se efetivamente a outros setores. É com base nessas estimativas que produzimos o índice do valor de produção do setor através do qual analisamos o crescimento agregado do setor.

\footnotetext{
${ }^{19}$ Os problemas aparecem sobretudo nos laminados, na medida em que as estatísticas de comércio exterior do Brasil incluem entre as "importações de ferro" uma série de produtos que não são característicos da produção propriamente siderúrgica, mas são produtos derivados. Por exemplo: arados, debulhadores, tratores, máquinas agrícolas, descaroçadores, locomotivas, prensas para algodão etc. A consequência é uma subestimativa, é verdade que não excessiva, por Baer da substituição de importações nesta faixa de produtos.

${ }^{20}$ Comércio Exterior do Brasil, vários anos.

${ }^{21} \mathrm{O}$ ferro-gusa e o aço, nesse caso, tipicamente em peças fundidas.
} 
Assim, este artigo traz uma contribuição específica no refinamento e expansão dos dados disponíveis para o setor a partir do cruzamento de fontes diversas. E também no uso analítico desses dados, que faremos a seguir.

\section{Crescimento e composição da produção siderúrgica brasileira}

Apesar da existência de diversas tentativas de produzir ferro localmente tanto no período colonial quanto durante o Império, por motivos vários, tais iniciativas, cada uma a seu tempo, malograram, e a siderurgia brasileira ingressou no século XX com muito pouca expressão prática. ${ }^{22} \mathrm{~A}$ produção anual de ferro na virada do século girou em torno de 3.000 t, quantidade não muito significativa frente às importações de ferro e aço, que, em 1901, foram de mais de 63.000 t. ${ }^{23}$ A produção de aço e a laminação eram inexistentes. Ademais, embora a produção doméstica não tenha crescido muito ao longo da década de 1900, a importação de ferro e aço expandiu-se fortemente, atingindo mais de $500 \mathrm{mil} \mathrm{t}$ em 1913. Os coeficientes de importação em quantidade para a década situavam-se em torno dos 99\%. Assim, ajustava-se bem ao tom do momento a circunstância da maior produtora nacional existente ser a Usina Esperança.

Desde o início do século XX até praticamente o fim da Primeira Guerra Mundial, além de um número de pequenas forjas espalhadas em Minas Gerais, havia no Brasil uma única empresa que produzia ferro-gusa - a Usina Esperança, que mais tarde passou a chamar-se Usina Queiroz Júnior - e nenhuma que produzisse aço ou laminados. A Queiroz Júnior expandiu sua produção de gusa lentamente durante esse período, acelerando este crescimento durante a Guerra, mas destinava sua produção sobretudo a peças fundidas, não procurando entrar na produção de aço e de laminados. Isso foi feito ao final da Guerra por duas outras empresas importadoras, a Cia. Mecânica e Importadora, de São Paulo, que iniciou em 1918 a produção de

\footnotetext{
${ }^{22}$ Veja Silva (1972); Baer (1969, cap. 4).

${ }^{23}$ As estimativas existentes para a produção anual de ferro na virada do século no geral não ultrapassam as $4.000 \mathrm{t}$, sendo $2.000 \mathrm{t}$ de ferro-gusa, e outras $2.000 \mathrm{t}$ de ferro forjado em aproximadamente 70 a 100 pequenas forjas espalhadas em Minas Gerais (Silva, 1945: 7; Bastos, 1959: 71; Baer, 1969: 56; Martins, 1976: 165-66; e Rady, 1973: 76). Contudo, com base nos dados mobilizados neste artigo, entende-se que uma melhor estimativa situaria a produção na virada do século em pouco menos de 3.000 t.
} 
aço e de laminados leves, e a Hime \& Cia., do Rio de Janeiro, que começou a produzir laminados leves por volta dessa época também. Depois da Guerra, e ao longo da década de 1920, mas concentrandose até o ano de 1926, houve um importante movimento de criação de empresas siderúrgicas no país. Entre 1917 e 1930, foram criadas 14 novas empresas no setor, diante de uma preexistente. Neste processo, destacam-se três empresas: a Cia. Siderúrgica Belgo-Mineira, fundada em 1921, a Cia. Brasileira de Mineração e Metalurgia, criada pela Cia. Mecânica e Importadora em 1925, e a Cia. Brasileira de Usinas Metalúrgicas, criada pela Hime \& Cia, em 1926. Essas três empresas não apenas dominaram o setor rapidamente, como também diversificaram a estrutura produtiva doméstica, entrando de forma mais incisiva na produção de aço e de laminados. Essas empresas, sobretudo a Belgo-Mineira, continuariam dominando o setor siderúrgico na década seguinte, apesar de um segundo surto de criação de novas empresas e de expansão da capacidade produtiva ocorrido na segunda metade da década de 1930. Em 1939, o setor já contava com 26 empresas, 11 das quais haviam sido criadas antes de 1930. Dentre as empresas preexistentes que expandiram sua capacidade produtiva na década de 1930, destacou-se, sem dúvida, a construção da Usina de Monlevade, inaugurada em 1937 pela Belgo-Mineira, que com isso assumiu uma clara posição de liderança individual no setor. ${ }^{24}$

Tal expansão da capacidade produtiva setorial refletia-se, naturalmente, também na produção. Contudo, enquanto a expansão da capacidade produtiva dava-se em momentos concentrados no tempo, o crescimento da produção ocorria de forma mais regular, mais gradual. O Gráfico 1 exibe a evolução da produção siderúrgica brasileira no período 1901 a 1940 em escala logarítmica, de forma a ressaltar a relativa estabilidade, considerado o período como um todo, das taxas de crescimento da produção de ferro-gusa, bem como da de aço e da de laminados, uma vez que estes produtos entram nas estatísticas. ${ }^{25}$

\footnotetext{
${ }^{24}$ Para uma descrição detalhada do processo de criação de empresas siderúrgicas e da expansão da capacidade produtiva no período veja Barros (2013). Sobre a Belgo-Mineira, em particular, veja Moyen (2007).

25 A produção de aço e laminados no país teve início já desde o final da Primeira Guerra, pela Cia. Mecânica e Importadora e, ao que tudo indica, também pela Hime \& Cia.. Além disso, entraram em operação antes de 1924 e 1925 - quando o aço e os laminados passam, respectivamente, a constar nas estatísticas oficiais - outras empresas produzindo esses produtos, como a Fábrica de Aço Paulista e a Cia. Eletro-Metalúrgica Brasileira. Os movimentos de maior amplitude da série de laminados anteriores a 1926 devem-se essencialmente a essas lacunas parciais nos dados.
} 
Cumpre notarmos aqui, antes de mais nada, a expansão sustentada da produção ao longo dessas quatro décadas, apesar de algumas quedas em anos específicos: nas conjunturas da Primeira Guerra e da Grande Depressão, bem como nos anos de 1926-27, quando a siderurgia passou por uma crise especificamente setorial, enfrentando dificuldades particularmente na realização da sua produção de ferro-gusa. Teremos ocasião adiante de discutir com maior atenção e rigor as taxas de crescimento setorial, porém, já podemos observar desde já que este gráfico sugere que são equiparáveis as taxas de crescimento da produção de cada um dos produtos do setor entre os diferentes subperíodos aqui contemplados e, particularmente, entre as décadas de 1920 e 1930.

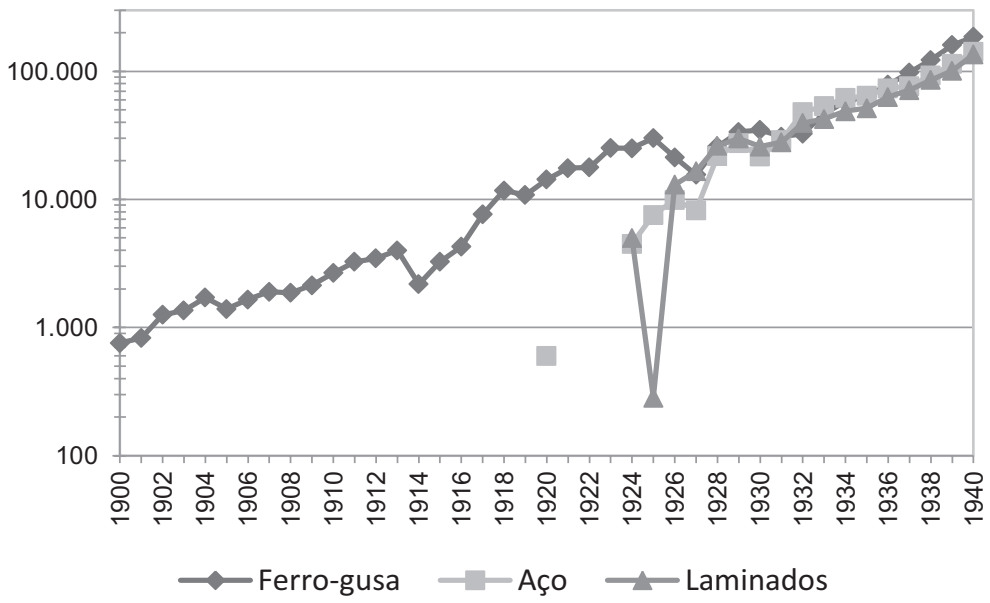

Gráfico 1 - Produção siderúrgica brasileira (1900-1940) (toneladas, escala logarítmica)

Fonte: Tabela A-1 anexa.

Uma perspectiva mais concreta sobre a dimensão absoluta do setor pode ser obtida no Gráfico 2, mostrando também as séries de produção, mas para o período de 1918 a 1940, em escala normal. Observamos que, se em 1918, o país produzira 12 mil t de ferrogusa, ele chegou em 1929 à produção de 34 mil t de ferro-gusa, 27 mil t de aço e 30 mil t de laminados. Ao longo da década de 1930, a expansão da produção foi também muito expressiva, tendo o país produzido, em 1940, 186 mil t de ferro-gusa, 141 mil t de aço e 135 mil t de laminados. 


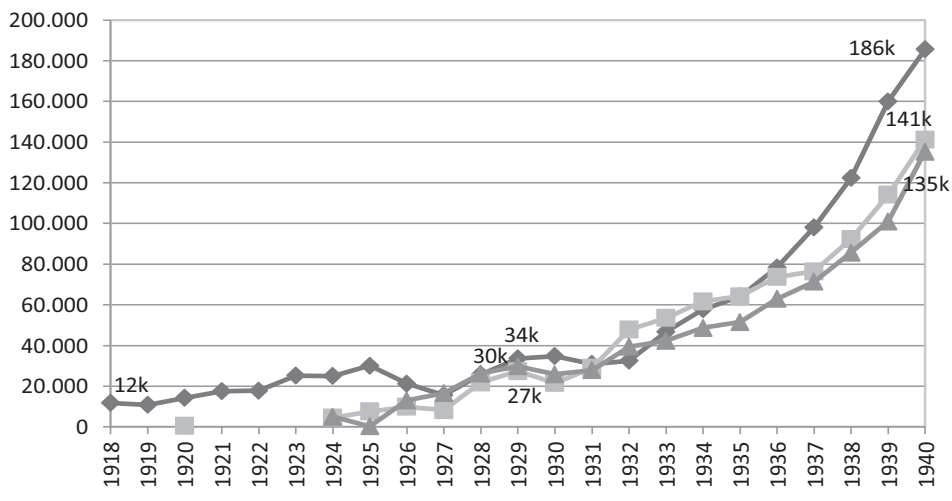

$\multimap$ Ferro-gusa $\longrightarrow$ Aço $\longrightarrow$ Laminados

Gráfico 2 - Produção siderúrgica brasileira (1918-1940) (toneladas)

Fonte: Tabela A-1, anexa.

Em outros termos, no imediato pós-Primeira Guerra e ao longo da década de 1920 o setor siderúrgico do país expandiu a sua produção de ferro-gusa e ingressou na produção de aço e de laminados, que rapidamente atingiram volumes de produção comparáveis aos de ferro-gusa. Na década de 1930, passado o impacto da depressão, o setor siderúrgico continuou crescendo vigorosamente. A produção de ferro-gusa, aumentou em 5,5 vezes entre 1929 e 1940. A de aço multiplicou-se por 5,2 no mesmo período e a de laminados por 4,5. A década de 1930 e o início da de 1940 caracterizaram-se, portanto, do ponto de vista do setor siderúrgico, inicialmente pelas repercussões da crise, com consequências negativas para quase todas as empresas ${ }^{26}$ seguida por um período de vigorosa retomada da produção com base em capacidade ociosa iniciado já a partir de 1931 e, após 1935, com a expansão da produção aliada à ampliação da capacidade produtiva das empresas existentes e criação de diversas novas empresas, sobretudo após $1937 .^{27}$

Outro aspecto relevante a analisarmos nesses dados diz respeito à composição da produção siderúrgica doméstica, que podemos observar nesse gráfico. Em que pese do crescimento expressivo ao longo

\footnotetext{
${ }^{26}$ Mas não para todas. A Belgo-Mineira, em particular, expandiu ano a ano continuamente a sua produção mesmo durante o período da crise. Como consequência, sua participação no mercado doméstico expandiu-se significativamente.

${ }^{27}$ Sobre a expansão da capacidade produtiva das empresas do setor no período veja Barros (2013).
} 
das décadas de 1920 e 1930 das três principais classes de produtos siderúrgicos - ferro-gusa, aço e laminados - chama a atenção o paralelismo na expansão dos três. Isso ressalta que o que está ocorrendo não é um mero crescimento de caráter extensivo, mas mais bem um aprofundamento da estrutura produtiva, no sentido de que o ferrogusa e o aço vão assumindo cada vez mais o papel de produtos intermediários dentro do setor, e os laminados vão se tornando o principal produto "final". Tal evolução deveu-se, sobretudo, ao crescimento das empresas relativamente mais verticalizadas do setor. De fato, o ferro-gusa, o aço e os laminados são, por um lado, "tipos" diferentes de produtos siderúrgicos e, por outro, são etapas do processo produtivo. Sem dúvida, o ferro-gusa e o aço podem ser empregados diretamente pelo setor siderúrgico ou por outros setores produtivos para a fabricação de produtos fundidos diversos - desde panelas, passando por tubos centrifugados, até peças para máquinas. Muitas das empresas siderúrgicas operando no país no período faziam isto diretamente. Contudo, à medida em que o setor se aprofunda na direção da produção de aço e particularmente na de laminados, ele expande as possibilidades de uso, e portanto o consumo, de seus próprios produtos, o ferro-gusa e o aço, que passam a ser utilizados também, e com o tempo predominantemente, como produtos intermediários. Se até 1917, todo o consumo aparente de ferro-gusa e aço tinha destinos "finais", à medida que o setor se desenvolvia, o consumo intermediário destes bens passou a ser cada vez mais importante, chegando eventualmente a predominar. Daí a necessidade de termos uma medida que contemple essas relações internas do setor para que possamos formar um quadro adequado sobre o crescimento do setor como um todo. Foi essa lacuna que procuramos preencher com a estimativa de um índice do valor da produção siderúrgica a valores constantes apresentado na Tabela A-3 anexa. Conforme discutido na seção 2 deste artigo, a estimativa desse índice procura separar aquilo que o setor siderúrgico vende para outros setores da economia daquilo que ele mesmo consome de seus próprios produtos, na tentativa de obter uma medida mais acurada do crescimento agregado do setor. As taxas de crescimento do setor entre 1919 e 1940 calculadas com base nesse índice são apresentadas no Gráfico 3. 


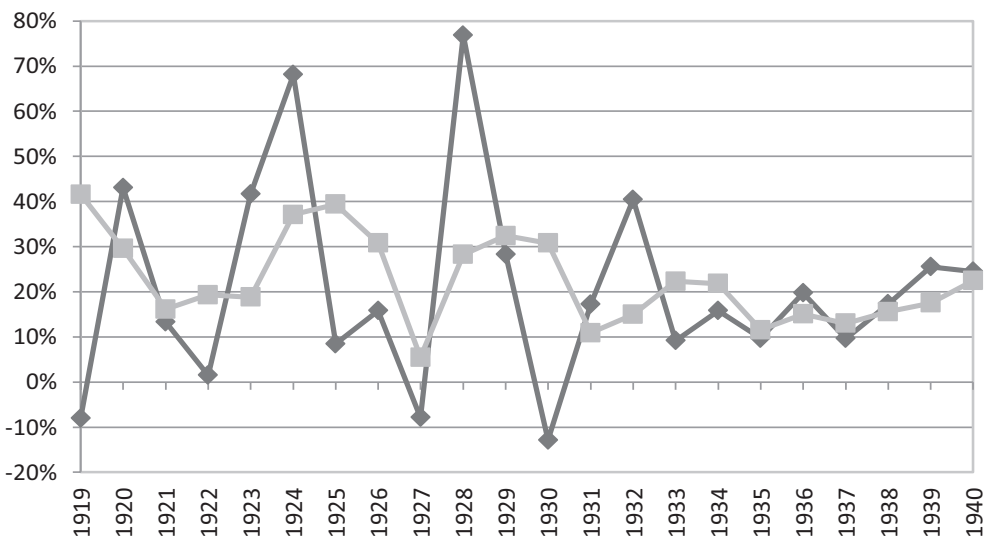

$\longrightarrow$ taxa de crescimento anual $\longrightarrow$ taxa de crestimento anual (média móvel 3 anos)

Gráfico 3 - Taxa de crescimento anual do setor siderúrgico (1919-1940)

Fonte: Calculado a partir dos dados da Tabela A-3, anexa.

Esse gráfico ressalta, antes de mais nada, as taxas bastante altas, apesar das oscilações, de crescimento do setor durante esse período que compreende as décadas de 1920 e 1930. Sem dúvida, como reconhece amplamente a historiografia, a década de 1930 foi marcada por uma grande expansão da produção siderúrgica doméstica. Contudo, devemos também ressaltar a importância da década de 1920 para o desenvolvimento do setor. Conforme observamos acima, a década de 1920 foi efetivamente um momento de criação de um número expressivo de novas empresas siderúrgicas. Mas a importância dessa década não se resume a isso. Um outro ponto de vista sobre a questão nos dá a comparação das taxas de crescimento do setor. No que diz respeito às taxas médias de crescimento, ambas as décadas apresentam expressivos resultados. A taxa média de crescimento do setor siderúrgico entre 1919 e 1929 foi de 26,3\% ao ano, enquanto que a taxa entre 1931 e 1940 foi de $18,7 \%$ ao ano. ${ }^{28}$ No entanto, como

${ }^{28}$ Taxas calculadas a partir do índice do valor da produção do setor siderúrgico a valores constantes da Tabela A-3, anexa. Essa comparação é qualitativamente robusta a diferentes seleções de anos limites para o cálculo:

$\begin{array}{llll}1921-1929 & 26,0 \% & 1930-1940 & 18,6 \% \\ 1923-1929 & 28,1 \% & 1932-1940 & 16,3 \% \\ 1925-1929 & 24,7 \% & 1932-1939 & 15,1 \% \\ 1923-1928 & 28,0 \% & 1930-1939 & 17,9 \% \\ 1925-1928 & 23,6 \% & 1931-1939 & 18,0 \%\end{array}$

Estud. Econ., São Paulo, vol.45, n.1, p. 153-183, jan.-mar. 2015 
podemos observar no Gráfico 3, a taxa de crescimento é mais estável e sustentada durante o período de crescimento após a depressão, e oscila muito mais fortemente ao longo dos anos 1920, vale dizer, o setor cresce antes da crise em saltos ou degraus, o que se deve, em parte, ao fato de o setor estar crescendo sobre uma base pequena ou, mais precisamente, relativamente menor que a dos anos 1930 e, em parte, ao processo de entrada de novas empresas. ${ }^{29}$

Contudo, a esse respeito, cabe ainda levar em consideração a capacidade produtiva, o que nos leva a observar duas coisas. ${ }^{30}$ Primeiro, da capacidade produtiva disponível em 1943, mais de um terço havia sido instalada até 1930. Segundo, o crescimento do setor na década de 1930 foi em boa medida baseado nesta capacidade. Por um lado, o crescimento da produção, pelo menos até 1936, esteve praticamente todo lastreado no parque existente antes da crise. Por outro, ao que tudo indica, os frutos desse crescimento inicial, nas condições de proteção alfandegária e favorecimento governamental disponíveis àquelas empresas, possibilitaram ou facilitaram a elas empreender um segundo pacote de investimentos no setor a partir de meados da década de 1930. Tais circunstâncias, aliadas aos favores de que gozavam as empresas criadas ou existentes na década de 1920, que colocavam-nas em franca vantagem frente a outras novas empresas que pretendessem entrar no setor, resultou em que todas as principais empresas do setor siderúrgico em 1940 fossem empresas criadas na década de 1920. Assim, não apenas o crescimento da década de 1920 é comparável ao da década de 1930, como também, em boa medida, a estrutura produtiva criada antes da crise forneceu parte das condições de possibilidade para a expressiva expansão que efetivamente se deu na década seguinte.

Outro aspecto relevante a observarmos nesses dados da produção siderúrgica brasileira é o impacto da crise do início dos anos 1930. Este não deixou de se fazer sentir no setor siderúrgico, como em geral, mas suas implicações foram moderadas e a retomada do setor foi particularmente rápida. ${ }^{31} \mathrm{O}$ valor da produção a valores constan-

29 Parte desse comportamento mais instável do índice do valor da produção na década de 1920, deve-se também, sem dúvida, a lacunas nos dados presentes nesse período, conforme discutido anteriormente. Contudo, cabe ressaltar que temos maior segurança sobre as taxas médias de crescimento para a década como um todo do que para as taxas de crescimento anuais ao longo da década de 1920, já que temos informação mais completa sobre a produção nos anos limite utilizados para o cálculo.

${ }^{30}$ Veja Barros (2013).

${ }^{31}$ Uma avaliação mais apropriada deste impacto do que anteriormente possível foi viabilizada 
tes caiu 12,9\% em 1930, mas já em 1931 retomou o pico de 1929. A retomada, contudo, tornou-se especialmente vigorosa em 1932, com um crescimento muito expressivo, de $41,3 \%$ do valor da produção, e já ultrapassando em 42,0\% o valor da produção de 1929. Em 1933 o setor continuou a crescer, mas em menor ritmo, 10,4\%, atingindo mais que o dobro do valor da produção de $1928 .{ }^{32}$

Um outro ponto de referência importante para avaliarmos esse processo de desenvolvimento do setor siderúrgico é a comparação com outros setores da economia, particularmente com o restante do setor industrial. O Gráfico 4 dá uma ideia bastante clara do dinamismo do setor siderúrgico brasileiro ao longo das décadas de 1920 e 1930, mesmo em relação ao conjunto da indústria de transformação do país.

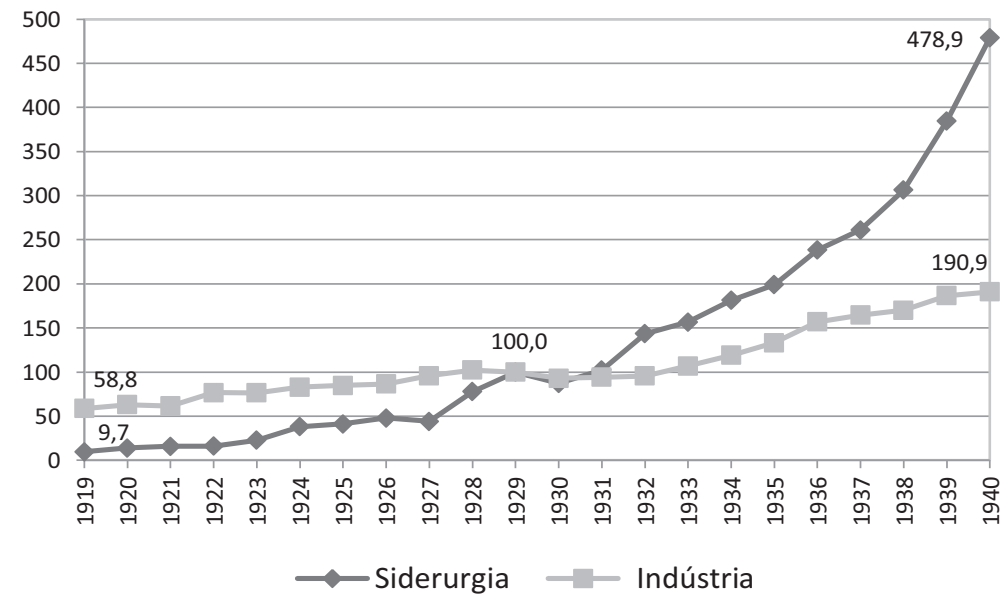

Gráfico 4 - Índices da produção industrial e da produção siderúrgica (1919-1940) $(1929=100)$

Fonte: Calculado a partir de IBGE (1990: 383-84) e da Tabela A-3, anexa.

pelo preenchimento de relevantes lacunas de dados para os anos de crise, conforme discutido na seção 2 deste artigo. Compare com Baer (1969: 60-1).

32 Podemos dizer que, qualitativamente, o setor siderúrgico vive no período um movimento similar ao da economia como um todo, mas mais acentuado. Ademais, a sua recuperação foi mais rápida e vigorosa do que a do resto da economia e mesmo que do resto da indústria. A título de comparação, a variação do nível real da atividade econômica brasileira foi de 1,1\% em $1929,-2,1 \%$ em 1930, -3,3\% em 1931 e, a partir do ano seguinte a economia volta a crescer, 4,3\% em 1932 e 8,9\% em 1933 (IBGE, 1990: 101, dados Claudio Haddad). Nestes mesmos anos, a variação real da produção industrial foi de, respectivamente, $-2,4 \%,-7,1 \%, 1,4 \%, 1,4 \%$ e 11,9\% (IBGE, 1990: 383-4). 
Considerando o dinamismo da indústria de transformação brasileira no período, particularmente na década de 1930, essa comparação é eloquente. De fato, como se depreende imediatamente do gráfico, entre 1919 e 1929, a produção industrial não chega a duplicar, enquanto a produção siderúrgica mais do que decuplica. Na década de 1930, a situação não é muito diferente. Enquanto, entre 1929 e 1940, a produção industrial como um todo cresceu 90,9\%, a produção siderúrgica aumentou $378,9 \%$, mais do que quatro vezes mais.

Mas esse crescimento médio da indústria de transformação inclui, com peso relativamente grande, setores industriais tradicionais, como o têxtil e o de alimentação, que são menos dinâmicos. Tendo isso em vista, a Tabela 1 fornece ainda outro ponto de comparação entre o desempenho do setor siderúrgico e os demais setores industriais individuais.

Tabela 1: Taxas de crescimento médio anuais de setores da indústria de transformação e do setor siderúrgico para períodos selecionados (1919-1939)

\begin{tabular}{|c|c|c|c|c|c|c|c|}
\hline & 1919 a 1939 & 1926 a 1939 & 1928 a 1939 & 1921 a 1929 & 1929 a 1932 & 1931 a 1939 & 1932 a 1939 \\
\hline Têxtil & $8,1 \%$ & $8,7 \%$ & $8,1 \%$ & $5,3 \%$ & $7,7 \%$ & $11,8 \%$ & $13,1 \%$ \\
\hline Chapéus & $2,6 \%$ & $2,8 \%$ & $-1,8 \%$ & $8,9 \%$ & $-21,4 \%$ & $7,1 \%$ & $9,7 \%$ \\
\hline Calçados & $4,8 \%$ & $4,6 \%$ & $3,4 \%$ & $8,4 \%$ & $-13,0 \%$ & $6,5 \%$ & $9,6 \%$ \\
\hline Couros e peles & $5,2 \%$ & $7,1 \%$ & $7,9 \%$ & $1,9 \%$ & $0,9 \%$ & $9,9 \%$ & $12,7 \%$ \\
\hline Fumo & $4,4 \%$ & $5,1 \%$ & $2,6 \%$ & $8,0 \%$ & $-3,2 \%$ & $4,0 \%$ & $4,9 \%$ \\
\hline Bebidas & $4,2 \%$ & $2,7 \%$ & $2,2 \%$ & $7,3 \%$ & $-9,2 \%$ & $6,7 \%$ & $7,3 \%$ \\
\hline Química & $9,6 \%$ & $6,5 \%$ & $5,8 \%$ & $15,4 \%$ & $-6,4 \%$ & $11,4 \%$ & $10,6 \%$ \\
\hline Papel & - & $15,1 \%(a)$ & $14,6 \%$ & - & $-5,4 \%$ & $17,4 \%$ & $21,9 \%$ \\
\hline Mobiliário & - & $10,0 \%$ & $10,7 \%$ & $9,1 \%$ & $-5,8 \%$ & $19,9 \%$ & $23,1 \%$ \\
\hline Alimentos & $3,4 \%$ & $3,3 \%$ & $3,2 \%$ & $4,4 \%$ & $-0,2 \%$ & $3,7 \%$ & $4,5 \%$ \\
\hline Cimento & - & $35,6 \%(a)$ & $20,7 \%$ & - & $15,7 \%$ & $19,6 \%$ & $24,6 \%$ \\
\hline Pneus & - & - & - & - & - & $63,1 \%(b)$ & $53,4 \%$ \\
\hline $\begin{array}{c}\text { Editorial e } \\
\text { Gráfica }\end{array}$ & - & $2,5 \%$ & $3,2 \%$ & $7,9 \%$ & $-12,6 \%$ & $9,1 \%$ & $9,2 \%$ \\
\hline $\begin{array}{c}\text { Total } \\
\text { Indústria de } \\
\text { Transformação }\end{array}$ & $5,9 \%$ & $6,1 \%$ & $5,6 \%$ & $6,3 \%$ & $-1,5 \%$ & $8,9 \%$ & $10,0 \%$ \\
\hline Siderurgia & $20,2 \%$ & $17,4 \%$ & $15,6 \%$ & $26,0 \%$ & $12,8 \%$ & $18,0 \%$ & $15,1 \%$ \\
\hline
\end{tabular}

Fonte: Para o setor siderúrgico, calculado a partir da Tabela A-3, anexa, para os demais setores, calculado a partir de IBGE (1990: 383-84).

Observações: "-" dados não disponíveis; (a) cálculo feito tendo por base dados do primeiro ano em que estatísticas de produção estão disponíveis para o setor; (b) cálculo feito tendo por base dados do segundo ano em que estatísticas de produção estão disponíveis para o setor (veja nota 33). 
Como podemos observar, o setor siderúrgico destaca-se sem ressalvas entre os setores industriais mais dinâmicos do país ao longo de todo o período. Entre 1919 e 1939, o setor siderúrgico cresceu à taxa média de 20,2\% a.a., enquanto nenhum outro setor para o qual é possível calcular a taxa nesse intervalo chegou a crescer a $10 \%$ a.a. Destacam-se, nesse intervalo, a indústria química, com crescimento de 9,6\% a.a., e a têxtil, com 8,4\% a.a. Mas isso se deve também, sem dúvida, ao fato de que alguns setores industriais particularmente dinâmicos não haviam entrado ainda nas estatísticas no ano de 1919, impossibilitando o cálculo a partir dessa base. Os setores de Papel e Cimento entram nas estatísticas em 1926. Tomando o período entre 1926 e 1939, esses setores cresceram a taxas bastante elevadas, respectivamente a $15,1 \%$ a.a. e $35,6 \%$ a.a., enquanto o setor siderúrgico cresceu, no mesmo período, a $17,4 \%$ a.a. Mas o cálculo da taxa de crescimento com base no primeiro ano de produção de um dado setor talvez não seja o melhor ponto de comparação. ${ }^{33}$ Tomando, então, o período entre 1928 (quando os setores Papel e Cimento já constavam nas estatísticas pelo terceiro ano) e 1939 temos que o setor de Cimento permanece o líder de crescimento, mas agora com uma taxa média de $20,7 \%$ a.a. O setor siderúrgico é o segundo setor industrial que mais cresceu no período, a $15,6 \%$ a.a., seguido dos setores de Papel e Mobiliário, respectivamente com taxas de 14,6\% a.a. e $10,7 \%$ a.a.

Durante os anos da crise, mais uma vez se destacam os setores de Cimento e Siderúrgico que cresceram, entre 1929 e 1932, em média $15,7 \%$ a.a. e $12,8 \%$ a.a. respectivamente, enquanto a indústria de transformação como um todo se contraía à taxa de $-1,5 \%$ a.a. Ao longo da década de 1930, depois de recuperada da crise a indústria, mais uma vez o setor siderúrgico encontra-se entre os que mais cresceram. Entre os anos de 1931 e 1939, o setor siderúrgico cresceu $18,0 \%$ a.a., enquanto o setor de Pneus cresceu à 63,1\% a.a., o setor de Mobiliário a 19,9\% a.a., o setor de Cimento a 19,6\% a.a. e o de Papel a 17,4\% a.a. Ou seja, nesses anos, com exceção do setor de Pneus, que em 1931 recém havia ingressado nas estatísticas, as taxas de crescimento dos setores de Mobiliário, Cimento, Siderurgia e Papel são bastante elevadas e similares entre si. Tomando o período

\footnotetext{
${ }^{33}$ A taxa de crescimento calculada para um determinado intervalo de anos é sensível à escolha do ano inicial da série já que o valor desse ano inicial entra como divisor na conta. E a produção do primeiro ano de um determinado setor, ou mesmo dos primeiros anos, é uma cifra algo fortuita e pode ser casualmente muito baixa (suponha, por exemplo, que a produção iniciou apenas no mês de outubro), inflando assim as taxas de crescimento calculadas.
} 
entre 1932 e 1939, o setor siderúrgico fica algo atrás dos setores de Cimento, Mobiliário e Papel, ${ }^{34}$ mas permanece com um desempenho bastante expressivo com relação aos demais setores industriais.

Com isso, tendo explorado esse quadro geral da evolução da produção siderúrgica no Brasil entre 1900 e 1940, seguiremos na próxima seção observando como esse processo de crescimento foi capaz de fazer frente à demanda através de um indicador particular, os coeficientes de importação.

\section{Evolução do coeficiente de importação}

Correspondendo à vigorosa expansão da produção doméstica, o coeficiente de importação de produtos siderúrgicos gradualmente também se comprimia. Até a Primeira Guerra, a quase totalidade da demanda por produtos siderúrgicos era suprida pela oferta externa, os coeficientes de importação globais do setor giravam em torno de 99\%. A queda do coeficiente de importação de ferro-gusa durante a Guerra esteve associada, sem dúvida, ao esforço da Queiroz Júnior, mas deveu-se, antes de mais nada, às restrições da oferta externa durante o conflito. Ainda assim, ao longo da década seguinte, com a criação de novas empresas produzindo ferro-gusa, o coeficiente de importações permaneceu mais baixo do que na primeira década do século, e chegou em 1929 a 15,7\% em valor e 12,6\% em quantidade. Ao longo da década de 1920 também os coeficientes de importação de aço e laminados sofreram alguma redução. Já notamos anteriormente que, até 1918, o Brasil era incapaz de produzir estes produtos. Contudo, em 1929, o coeficiente de importação de aço já se situava em $68,9 \%$ em valor e $74,5 \%$ em quantidade, e o de laminados em $88,4 \%$ em valor e $90,7 \%$ em quantidade. Esse movimento teve continuidade ao longo da década de 1930. Em 1940, os coeficientes em valor para ferro-gusa, aço e laminados atingiram, respectivamente, $2,0 \%, 25,1 \%$ e $76,1 \%$, enquanto os coeficientes em quantidade foram de $0,3 \%, 12,0 \%$ e $65,5 \%$. Essa evolução pode ser melhor visualizada nos Gráficos 5a e 5b.

\footnotetext{
${ }^{34}$ Isso se deve, sem dúvida, à recuperação precoce e particularmente vigorosa do setor siderúrgico, como vimos acima. O crescimento do setor de 17,2\% em 1931 e o de 40,5\% em 1932 ficam de fora desse intervalo.
} 


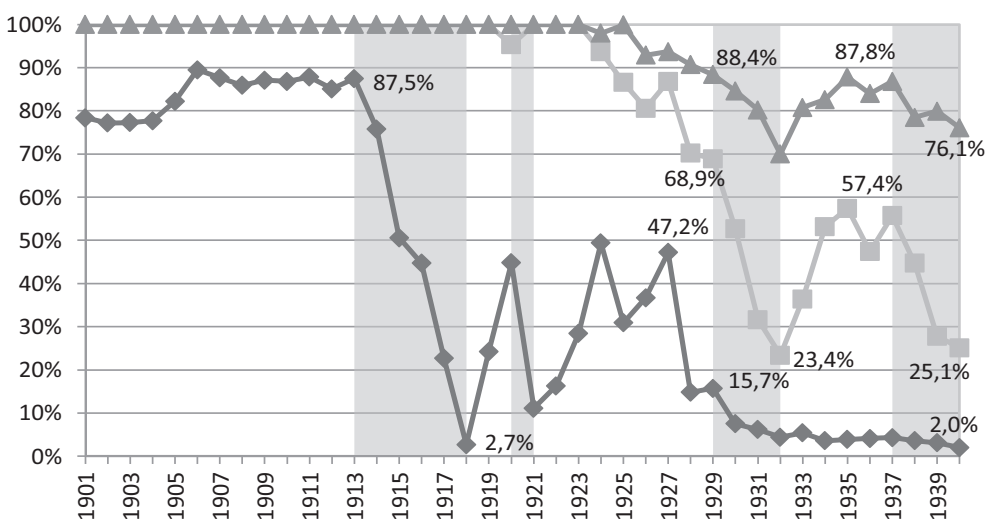

$\multimap$ Ferro-gusa $\longleftarrow$ Aço $\longrightarrow$ Laminados

Gráfico 5a - Coeficiente de importação de produtos siderúrgicos (valor), 19011940

Fonte: Tabela A-2, anexa.

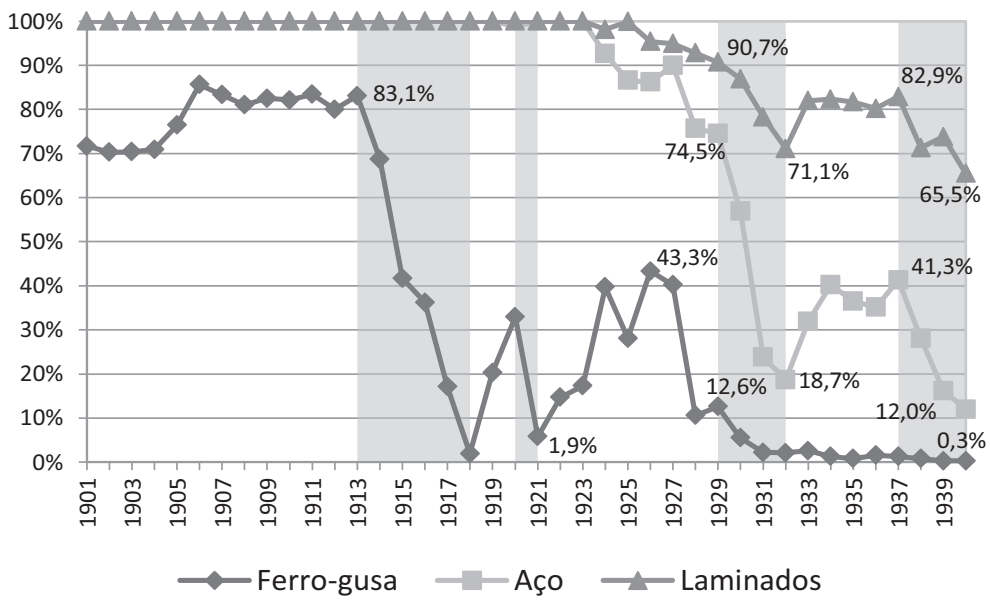

Gráfico 5b - Coeficiente de importação de produtos siderúrgicos (quantidade), 1901-1940

Fonte: Tabela A-2, anexa.

É interessante observarmos os efeitos da crise de 1929 também a partir dos coeficientes de importação. A queda nas importações de produtos de ferro e aço foi significativa durante a crise. Os coeficientes de importação em quantidade para ferro-gusa e aço passaram, 
entre 1929 a 1932, respectivamente de $12,6 \%$ para $2,1 \%$ e de $74,5 \%$ para $18,7 \%$. Os coeficientes de importação de laminados também sofreram reduções, mas de menor monta, de $90,7 \%$ para $71,1 \%$ em quantidade e de $88,4 \%$ para $70,0 \%$ em valor. Isto se deu sobretudo com a queda das importações, ou seja, devido à restrição externa. Como vimos, a produção doméstica sofreu um impacto inicial em 1930, mas já em 1931 retomava níveis de produção semelhantes aos de 1929. As importações de produtos de ferro e aço, por sua vez, sofreram queda maior do que a média das importações nestes anos, passando de $6,1 \%$ das importações totais em 1929 para 5,2\% em 1931.

Esse comportamento dos coeficientes de importação durante o período da Grande Depressão sugere a importância da restrição às importações em momentos de estrangulamento externo mais agudo para a redução dos coeficientes, que pode ser observado de forma mais geral. De fato, os episódios de contração mais acentuada dos coeficientes de importação que podemos observar nas séries exibidas nos Gráficos $5 \mathrm{a}$ e $5 \mathrm{~b}$ estiveram associados a momentos de forte retração das importações em situações de dificuldades no setor externo. Para examinarmos essa questão com maior detalhe, o Gráfico 6 mostra o comportamento das importações totais de produtos siderúrgicos entre 1901 e 1940. Um primeiro ponto a destacar nesse gráfico é que as importações de produtos siderúrgicos estiveram sujeitas, nesse período, a episódios recorrentes de grande contração. Os dois momentos de mais marcantes desse padrão foram os períodos da Primeira Guerra Mundial e da Grande Depressão, mas outros também aparecem com clareza no gráfico, como o ano de 1921 e o período após 1937. ${ }^{35}$ Esses correspondem, de fato, aos momentos de estrangulamento externo, maior ou menor, vividos pela economia brasileira como um todo ao longo do período em análise. Mais do que isso, as contrações das importações de produtos siderúrgicos são mais fortes do que as das importações gerais na medida em que, tipicamente, nos momentos de crise, as importações de produtos siderúrgicos perdiam participação nas importações totais. Nesse sentido, as importações de produtos siderúrgicos, não apenas acompanhavam mas experimentavam de forma amplificada os movimentos do setor externo.

35 Esse movimento de redução das importações de produtos siderúrgicos ao final da década de 1930 terá continuidade para além do período em análise aqui, atingindo 111 mil t em 1942. 


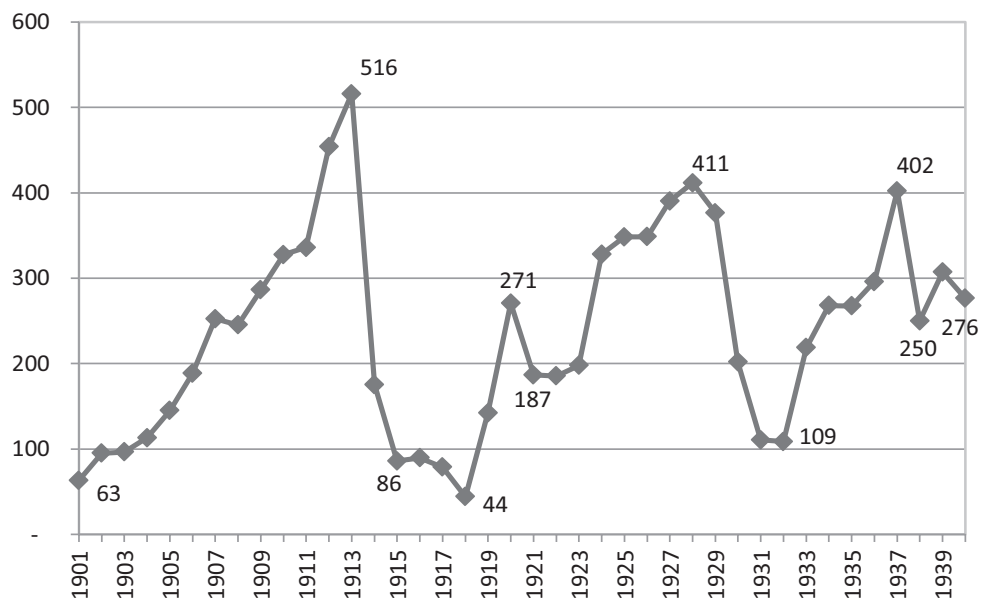

Gráfico 6 - Importações totais de produtos siderúrgicos (mil t) (1901-1940) Fonte: Barros (2011: 215-16)

O segundo ponto a ressaltar dos Gráficos 5 e 6 conjuntamente é justamente que os episódios de contração das importações de produtos siderúrgicos correspondem precisamente aos momentos de redução mais acentuada nos coeficientes de importação de produtos siderúrgicos. Em particular, o ano de 1921 e, sobretudo, os da Primeira Guerra Mundial são de grande redução nos coeficientes de importação de ferro-gusa. Já os períodos da Grande Depressão e do final da década de 1930 são momentos de quedas acentuadas nos coeficientes de importação de aço e laminados. Visando destacar essa correspondência, os períodos de grande retração das importações de produtos siderúrgicos foram sombreados nos Gráficos $5 \mathrm{a}$ e $5 \mathrm{~b}$.

Que o coeficiente de importações caia com a queda das importações é algo praticamente forçoso, há razões econômicas suficientes para isso e, podemos dizer, esse é até mesmo um efeito algébrico do movimento. ${ }^{36}$ Contudo, a evolução de longo prazo dos coeficientes de importação de produtos siderúrgicos no sentido de sua queda e, assim, da substituição de importações no setor, não se resume à mera contração cíclica das importações desses produtos. A esse respeito, a primeira coisa a observar é que o processo de expansão do setor

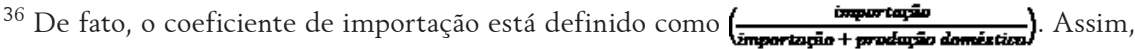
dada uma queda qualquer da importação, o coeficiente só não cai se a produção doméstica for zero, ou se cair proporcionalmente à importação.
} 
siderúrgico ao longo da década de 1920 já vinha se manifestando na forma de uma redução gradual dos coeficientes de importação antes de 1929. O coeficiente de importação em quantidade de ferro-gusa cai de 43,3\% em 1927 para 12,6\% em 1929. Já os coeficientes de importação em quantidade de aço e laminados caem de $100 \%$ em 1923 para, respectivamente, 74,5\% e 90,7\% em 1929.

Em segundo lugar, a relação entre a contração das importações e a redução dos coeficientes de importação de produtos siderúrgicos é menos linear do que faria supor a álgebra. Sem dúvida, como já observamos, as quedas cíclicas das importações de produtos siderúrgicos se manifesta na forma de uma praticamente necessária queda correspondente nos coeficientes de importação desses produtos. Porém, uma vez amenizada a restrição às importações, os coeficientes de importação invertem o movimento e voltam a subir em alguma medida, mas - e esse é o ponto a destacar - não retornam mais aos mesmos patamares anteriores. Em outras palavras, a expansão da produção interna como resposta ao estrangulamento externo era incorporada de forma perene ao coeficiente de importações mesmo após o alívio das restrições às importações e a recuperação destas.

No período que antecedeu a Primeira Guerra, o coeficiente de importação de ferro-gusa girava em torno de pouco mais de $80 \% .{ }^{37}$ Entre 1913 e 1918, ele colapsa de 83,1\% para 1,9\%. Após o término da Guerra, ele se recupera, atingindo 32,9\% em 1920, para novamente cair para 5,8\% em 1921, retomando uma trajetória ascendente a partir de então, atingindo um novo pico de 43,3\% em 1926, num patamar bastante inferior aos mais de $80 \%$ vigentes antes da Primeira Guerra. Um movimento similar foi vivenciado pelos coeficientes de importação de aço e laminados durante a Grande Depressão e o período que a seguiu. O coeficiente de importação de aço, que havia sido de $74,5 \%$ em 1929, atinge $18,7 \%$ em 1932, e se recupera depois disso, mas para um novo patamar mais baixo, de em torno de $35 \%$ a 40\% entre 1934 e 1937. O coeficiente de importações de laminados, por sua vez, que foi de 90,7\% em 1929, caiu para 71,1\% em 1932 com a crise e depois também se recuperou, mas igualmente para um patamar mais baixo que o prevalecente antes da crise, de pouco mais de $80 \%$ entre 1933 e 1937. Assim, em meio às oscilações do setor externo e, em parte, mesmo através delas, o desenvolvimento do

${ }^{37}$ Nessa análise, atenho-me aos coeficientes de importação em quantidade. 
setor ao longo do período era acompanhado de um correspondente processo de substituição de importações.

Contudo, ao analisarmos a contração do coeficiente de importação dos produtos siderúrgicos, devemos ter em conta duas circunstâncias adicionais. Primeiro, o aprofundamento da estrutura produtiva do setor, com a crescente importância do consumo de ferro-gusa e aço como insumos para a produção de laminados dentro do próprio setor siderúrgico doméstico, como tivemos ocasião de observar acima. E segundo, a importância muito superior do consumo de laminados frente aos demais tipos de produtos siderúrgicos. De fato, um exame dos dados de consumo aparente final ressalta a clara predominância dos produtos laminados na composição da demanda por produtos siderúrgicos. ${ }^{38}$ Os laminados foram responsáveis por em torno de $80 \%$, em média, do consumo aparente final de produtos siderúrgicos entre 1901 e 1940. Neste mesmo período, a mesma proporção tomada em valor tem tendência levemente ascendente, passando de em torno de $80 \%$ para em torno de $90 \%$. De fato, se o ferro-gusa e o aço podem atender a uma demanda fora do setor siderúrgico na forma de produtos fundidos, é sem dúvida nos produtos resultantes da conformação mecânica do aço, tipicamente feita por laminação, que reside o núcleo do setor siderúrgico. Ou seja, os laminados eram, sem lugar a dúvida, a maior parcela do consumo de produtos siderúrgicos.

Assim, a constatação de que o Brasil havia atingido baixos coeficientes de importação de ferro-gusa já em 1930 e de que produzia praticamente todo o ferro-gusa e quase todo o aço que consumia em 1940 deve ser tomada com cautela. Tais dados indicam antes um gargalo produtivo na etapa da laminação, do que um "cumprimento" na substituição de importação das etapas anteriores. De fato, não podemos deixar de observar que, apesar dos avanços realizados na década, o principal item na pauta do setor ainda era em valor três quartas partes importado. Em outras palavras, o parco desenvolvimento da laminação mascarava uma demanda latente por ferro-gusa e aço, tomados como bens intermediários. Além disso, justamente por sua posição de gargalo, a expansão da produção da laminação assumiu o papel de elemento dinâmico principal da evolução do setor, especialmente depois de 1930. De fato, a capacidade ociosa do setor na laminação parece ter sido regularmente inferior às das demais etapas produtivas do setor no período. Assim, uma vez que o consu-

38 Veja Barros (2011, Apêndice estatístico).

Estud. Econ., São Paulo, vol.45, n.1, p. 153-183, jan.-mar. 2015 
mo intermediário de ferro-gusa e de aço tornou-se mais relevante, o passo da expansão da capacidade e da produção de laminados passou a ditar o ritmo de desenvolvimento do setor siderúrgico inteiro.

Ainda assim, não devemos menosprezar as realizações do setor. Em primeiro lugar, que o setor atendesse, em 1940, 99,7\% do consumo aparente interno de ferro-gusa, $88,0 \%$ do de aço e $34,5 \%$ do de laminados é um resultado significativo. Em segundo lugar, é difícil deixar de reconhecer a dinamicidade de um setor que cresceu a uma taxa média de 20,4\% ao ano por mais de 20 anos (entre 1919 e 1940).

\section{Considerações finais}

Tendo acompanhado o processo de desenvolvimento do setor siderúrgico ao longo das quatro primeiras décadas do século XX, cumprenos fazer algumas considerações finais.

O período foi marcado pela expansão da produção siderúrgica e da capacidade produtiva do setor, e por algum grau de diversificação e aprofundamento produtivos. O setor siderúrgico ingressara no século XX com uma produção de pequeno significado prático. Em 1918, iniciou-se a produção de aço e de laminados leves. Entre 1919 e 1929, surgiu uma série de novas empresas, oito das quais estariam ainda em funcionamento em 1939, mas das quais três se destacam por avançarem às etapas da produção de aço e laminação - a Belgo-Mineira, a Cia. Brasileira de Mineração e Metalurgia e a Cia. Brasileira de Usinas Metalúrgicas. Em 1929, o país já produzia 33,7 mil t de ferro-gusa, 27,4 mil t de aço e 29,8 mil t de laminados. Os coeficientes de importação em atingiram então $15,7 \%$ para o ferrogusa, $68,9 \%$ para o aço e $88,4 \%$ para os laminados. Na década de 1930 teve continuidade o processo de desenvolvimento do setor, com aumentos expressivos da produção já a partir de 1931 e, na segunda metade da década de 1930, houve nova onda de investimento no setor, com criação de várias novas empresas e expansão das existentes. Em 1939, 26 empresas operavam no setor. No ano seguinte, a produção foi de 186 mil $t$ de ferro-gusa, 141 mil $t$ de aço e 135 mil t de laminados, sendo os coeficientes de importação, respectivamente, $2,0 \%, 25,1 \%$ e $76,1 \%$. 
Contudo, tal desenvolvimento do setor siderúrgico, durante as quatro primeiras décadas do século XX, não colocava o parque produtivo doméstico em condições de atender plenamente a demanda doméstica. Ainda que o coeficiente de importação de ferro-gusa em valor em 1940 tenha atingido 2,0\% o de aço permanecia em 25,1\% e, o que é mais importante, o de laminados era de $76,1 \%$. De fato, havia limitações qualitativas para o atendimento da demanda doméstica, já que alguns dos principais itens da pauta de importações - como trilhos, chapas e folhas de Flandres - absolutamente não podiam ser produzidos pelas empresas em operação no Brasil.

A despeito dessas limitações do setor siderúrgico brasileiro, tanto quantitativas quanto qualitativas, não podemos deixar de ressaltar o significado e a importância desse desenvolvimento setorial ocorrido nas décadas anteriores à criação da Companhia Siderúrgica Nacional. Os avanços foram expressivos, como fica patente se tivermos em conta que a taxa de crescimento média do setor entre 1919 e 1940 foi de nada menos que $20,4 \%$ ao ano, cifra bastante expressiva mesmo em comparação com outros setores industriais especialmente dinâmicos. De fato, tendo isso em vista, podemos notar sem reservas que a capacidade produtiva siderúrgica já instalada em 1943 no país - da ordem de $280 \mathrm{mil} \mathrm{t} / \mathrm{ano}$ de ferro-gusa e aço e de $170 \mathrm{mil}$ t/ano de laminados - se comparava à capacidade planejada da usina de Volta Redonda então em construção, que era de em torno de 300 mil t/ ano de laminados. ${ }^{39}$

\footnotetext{
${ }^{39}$ Para a estimativa da capacidade produtiva do setor siderúrgico brasileiro em 1943, veja Barros (2013: 27-9). Para o programa de produção da usina de Volta Redonda veja Comissão Executiva do Plano Siderúrgico Nacional (1940-1941: vii). De fato, o crescimento da capacidade produtiva foi afetada pela conjuntura de guerra na primeira metade dos anos 1940. Contudo, já em 1947, ano anterior à inauguração da seção de laminados da usina de Volta Redonda, o restante do setor produziu pouco menos de 270 mil t de laminados.
} 


\section{Referências ${ }^{40}$}

\subsection{Publicações seriadas}

- Boletim do Serviço Geologico e Mineralogico do Brasil, Ministerio da Agricultura, Industria e Commercio (BSGM).

- Comércio Exterior do Brasil, vários números, [anos abrangidos (ano de publicação)].

- Serviço de Estatistica Commercial. Importação geral, 1901 (s.d.).

- Serviço de Estatistica Commercial. Importação e exportação, movimento maritimo, cambial e do café, 1903 (1905), 1904 (1906).

- Ministerio da Fazenda, Serviço de Estatistica Commercial. Importação e exportação, movimento maritimo, cambial e do café, 1905 (1907), 1906 (1907), 1907 (1909), 1908 (1909), 1909 (1911).

- Ministerio da Fazenda, Directoria de Estatistica Commercial. Commercio Exterior do Brasil, 1910-1914 (s.d.), 1913-1918 (1921).

- Ministerio da Fazenda, Directoria de Estatistica Commercial. Commercio Exterior do Brasil, Resumo por mercadorias, Movimento maritimo, Movimento bancario, 1912-1913 (1914), 1914-1915 (1916), 1915-1919 (1920), 1918-1922 (1923), 1919-1923 (1924), 1920-1924 (1925), 1921-1925 (1926), 1922-1926 (1927), 1924-1928 (1929), 1928-1929 (1930), 1929-1930 (1931), 1930-1931 (1932).

- Departamento Nacional de Estatistica (Ministerio do Trabalho, Industria e Commercio). Commercio Exterior do Brasil, Resumo por mercadorias, 1931-1932 (1933).

- Directoria de Estatistica Economica e Financeira do Thesouro Nacional (Ministerio da Fazenda). Commercio Exterior do Brasil, Resumo por mercadorias, 1929-1933 (1934), 1930-1934 (1935), 1932-1936 (1937).

- Serviço de Estatística Econômica e Financeira do Tesouro Nacional (Ministério da Fazenda), Comércio Exterior do Brasil - Importação, Exportação, 1937-1938 (1941).

- Serviço de Estatística Econômica e Financeira do Tesouro Nacional (Ministério da Fazenda). Comércio Exterior do Brasil, Resumo por mercadorias, 1939 (1940), 1940 (1941).

\subsection{Fontes on-line}

- Legislação Federal, em <http://www2.camara.leg.br/atividade-legislativa/legislacao>.

\subsection{Publicações}

BAER, Werner. The development of the Brazilian steel industry. Nashville, TN: Vanderbilt University Press, 1969.

\footnotetext{
${ }^{40}$ Aqui constam apenas os trabalhos referidos ao longo do texto. Contudo, o conjunto de fontes utilizado para os levantamentos aqui consolidados é bastante mais amplo, e está indiretamente referido em meus trabalhos anteriores aqui citados. Os arquivos consultados de forma mais sistemática incluem o Arquivo Nacional (especialmente Fundos do Conselho Nacional de Economia e do Gabinete Civil da Presidência da República), o Centro de Pesquisa e Documentação de História Contemporânea do Brasil (CPDOC) (com destaque para as coleções de Edmundo de Macedo Soares, Getúlio Vargas e Juarez Távora), a Biblioteca do Ministério da Fazenda no Rio de Janeiro (Biblioteca Domingos Marques Grello) entre outros. Para maiores detalhes sobre o conjunto de fontes subjacente a este trabalho veja Barros (2011).
} 
BAER, Werner. The steel industry. In: BERGSMAN, Joel. Brazil: Industrialization and trade policies. London: Oxford University Press, p. 191-221, 1970.

BARROS, Gustavo. O Problema siderúrgico nacional na Primeira República. Tese de doutorado, Departamento de Economia, FEA-USP, São Paulo, 2011. Disponível em: < http://www.teses.usp. br/teses/disponiveis/12/12138/tde-24012012-135049/>.

BARROS, Gustavo. O Desenvolvimento do setor siderúrgico brasileiro entre 1900 e 1940: Criação de empresas e evolução da capacidade produtiva. Revista de História Econômica e Economia Regional Aplicada (HEERA), Juiz de Fora: UFJF, v. 8, n. 14, jan-jun 2013. p. 9-32. Disponível em: $<$ http://www.ufjf.br/heera/>.

BASTOS, Humberto. A conquista siderúrgica no Brasil: Crônica e interpretação econômica das empresas e indivíduos, nacionais e estrangeiros, que participaram da exploração dos recursos minerais do desenvolvimento nacional. São Paulo: Livraria Martins Editora, 1959.

CARVALHO, Elysio de. Brasil, potencia mundial - Inquerito sobre a industria siderurgica no Brasil. Rio de Janeiro: Monitor Mercantil, 1919.

COMISSÃO EXECUTIVA DO PLANO SIDERÚRGICO NACIONAL. Relatório, Rio de Janeiro, 1940-1941.

FELICÍSSIMO JUNIOR, Jesuino. História da siderurgia de São Paulo, seus personagens e seus feitos. São Paulo: ABM, 1969.

GOMES, Francisco M. História da siderurgia no Brasil. Belo Horizonte: Itatiaia; São Paulo: Edusp, 1983.

GONSALVES, Alpheu Diniz. Ferro no Brasil - Historia, Estatistica e Bibliographia. Boletim n. 61, Serviço Geologico e Mineralogico do Brasil, Ministerio da Agricultura. Rio de Janeiro: Typ. do Ministério da Agricultura, 1932.

GONSALVES, Alpheu Diniz. O ferro na economia nacional. Rio de Janeiro: Ministério da Agricultura, 1937.

INSTITUTO BRASILEIRO DE GEOGRAFIA E ESTATÍSTICA (IBGE). Estatísticas históricas do Brasil: Séries econômicas, demográficas e sociais de 1550 a 1988. 2a ed. revista e atualizada do vol. 3 de Séries estatísticas retrospectivas, Rio de Janeiro: IBGE, 1990.

JOBIM, José. The mineral wealth of Brazil. Rio de Janeiro: Livraria José Olympio Editora, 1941.

MARTINS, Luciano. Pouvoir et développement économique: formation et évolution des structures politiques au Brésil. Paris: Antrophos, 1976.

MOYEN, François. A História da Companhia Siderúrgica Belgo-Mineira: Uma trajetória de crescimento consistente (1921-2005). 1ª ed., Belo Horizonte: Belgo, Fundação Belgo - Grupo Arcelor, 2007.

PELÁEZ, Carlos Manuel. História da industrialização brasileira: Crítica à teoria estruturalista no Brasil. Rio de Janeiro: APEC, 1972.

RADY, Donald E. Volta Redonda: A steel mill comes to a Brazilian coffee plantation, Industrial entrepreneurship in a developing economy. Albuquerque, New Mexico: Rio Grande Publ., 1973.

SILVA, Edmundo de Macedo Soares e. Volta Redonda: gênese da idéia, seu desenvolvimento, projeto, execução e custo. Separata da Revista do Serviço Público, Ano VIII, Vol. VI, n. 2, Rio de Janeiro: Imprensa Nacional, 1945.

SILVA, Edmundo de Macedo Soares e. O Ferro na história e na economia do Brasil. Rio de Janeiro: [Comissão Executiva Central do Sesquicentenário da Independência do Brasil], 1972.

VARGAS, Getulio. A Nova Política do Brasil, V - O Estado Novo, 10 de Novembro de 1937 a 25 de Julho de 1938, Rio de Janeiro: Livraria José Olympio Editora, 1938.

WIRTH, John D. The politics of Brazilian development, 1930-1954. Stanford, CA: Stanford University Press, 1970. 


\section{Anexos}

Tabela A-1 - Produção de ferro e aço no Brasil, 1899-194

\begin{tabular}{|c|c|c|c|c|c|c|c|c|}
\hline & \multicolumn{2}{|c|}{ Ferro-gusa } & \multicolumn{2}{|c|}{ Aço } & \multicolumn{2}{|c|}{ Laminados } & \multicolumn{2}{|c|}{ Total ferro e aço } \\
\hline & $(\mathrm{t})$ & (mil-réis) & $(\mathrm{t})$ & (mil-réis) & $(\mathrm{t})$ & (mil-réis) & $(\mathrm{t})$ & (mil-réis) \\
\hline 1899 & 80 & - & & & & & 80 & - \\
\hline 1900 & 756 & - & & & & & 756 & - \\
\hline 1901 & 826 & 53.436 & & & & & 826 & 53.436 \\
\hline 1902 & 1.258 & 77.123 & & & & & 1.258 & 77.123 \\
\hline 1903 & 1.360 & 79.209 & & & & & 1.360 & 79.209 \\
\hline 1904 & 1.710 & 87.549 & & & & & 1.710 & 87.549 \\
\hline 1905 & 1.394 & 63.681 & & & & & 1.394 & 63.681 \\
\hline 1906 & 1.654 & 93.417 & & & & & 1.654 & 93.417 \\
\hline 1907 & 1.901 & 82.378 & & & & & 1.901 & 82.378 \\
\hline 1908 & 1.868 & 111.756 & & & & & 1.868 & 111.756 \\
\hline 1909 & 2.134 & 112.122 & & & & & 2.134 & 112.122 \\
\hline 1910 & 2.659 & 140.356 & & & & & 2.659 & 140.356 \\
\hline 1911 & 3.262 & 161.527 & & & & & 3.262 & 161.527 \\
\hline 1912 & 3.463 & 202.160 & & & & & 3.463 & 202.160 \\
\hline 1913 & 4.000 & 236.517 & & & & & 4.000 & 236.517 \\
\hline 1914 & 2.181 & 131.645 & & & & & 2.181 & 131.645 \\
\hline 1915 & 3.259 & 273.899 & & & & & 3.259 & 273.899 \\
\hline 1916 & 4.267 & 485.534 & & & & & 4.267 & 485.534 \\
\hline 1917 & 7.648 & 1.285 .816 & & & & & 7.648 & 1.285 .816 \\
\hline 1918 & 11.748 & 3.812 .198 & - & - & - & - & 11.748 & 3.812 .198 \\
\hline 1919 & 10.808 & 2.485 .840 & - & - & - & - & 10.808 & 2.485 .840 \\
\hline 1920 & 14.285 & 3.285 .550 & 600 & 1.587 .246 & - & - & 14.885 & 4.872 .796 \\
\hline 1921 & 17.518 & 4.029 .140 & - & - & - & - & 17.518 & 4.029 .140 \\
\hline 1922 & 17.783 & 4.090 .090 & - & - & - & - & 17.783 & 4.090 .090 \\
\hline 1923 & 25.187 & 5.037 .400 & - & - & - & - & 25.187 & 5.037 .400 \\
\hline 1924 & 25.035 & 5.188 .330 & 4.492 & 2.021 .400 & 5.000 & 4.000 .000 & 34.527 & 11.209 .730 \\
\hline 1925 & 30.046 & 6.958 .430 & 7.559 & 3.654 .173 & 283 & 226.400 & 37.888 & 10.839 .003 \\
\hline 1926 & 21.279 & 5.541 .654 & 9.895 & 5.199 .237 & 13.051 & 10.440 .800 & 44.225 & 21.181 .691 \\
\hline 1927 & 15.584 & 4.181 .404 & 8.205 & 4.500 .998 & 16.539 & 13.231 .200 & 40.328 & 21.913 .602 \\
\hline 1928 & 25.762 & 6.745 .844 & 21.830 & 11.933 .621 & 26.227 & 20.981 .600 & 73.819 & 39.661 .065 \\
\hline 1929 & 33.671 & 8.409 .334 & 27.381 & 14.497 .785 & 29.790 & 23.832 .000 & 90.842 & 46.739 .119 \\
\hline 1930 & 34.805 & 8.745 .460 & 21.573 & 11.589 .536 & 25.873 & 20.698 .400 & 82.251 & 41.033 .396 \\
\hline 1931 & 30.906 & 7.066 .923 & 28.998 & 14.370 .858 & 27.894 & 22.315 .245 & 87.798 & 43.753 .027 \\
\hline 1932 & 32.525 & 7.412 .348 & 47.828 & 22.935 .703 & 39.353 & 31.482 .490 & 119.706 & 61.830 .541 \\
\hline 1933 & 46.774 & 11.670 .894 & 53.566 & 24.646 .350 & 42.354 & 33.883 .200 & 142.694 & 70.200 .444 \\
\hline 1934 & 57.784 & 14.492 .501 & 61.673 & 23.949 .730 & 48.699 & 38.990 .481 & 168.156 & 77.432 .712 \\
\hline 1935 & 64.082 & 14.957 .139 & 64.231 & 25.278 .459 & 51.513 & 39.347 .057 & 179.826 & 79.582 .655 \\
\hline 1936 & 78.419 & 23.564 .342 & 73.667 & 45.311 .295 & 62.946 & 61.387 .255 & 215.032 & 130.262 .892 \\
\hline 1937 & 98.101 & 33.452 .000 & 76.430 & 55.663 .000 & 71.419 & 76.248 .000 & 245.950 & 165.363 .000 \\
\hline 1938 & 122.352 & 48.000 .000 & 92.420 & 72.135 .000 & 85.666 & 100.422 .000 & 300.438 & 220.557 .000 \\
\hline 1939 & 160.016 & 59.434 .000 & 114.095 & 90.169 .000 & 100.996 & 113.755 .000 & 375.107 & 263.358 .000 \\
\hline 1940 & 185.570 & 69.010 .000 & 141.201 & 113.308 .000 & 135.293 & 157.942 .000 & 462.064 & 340.260 .000 \\
\hline
\end{tabular}

Fonte: Barros (2011: 211). Observações: "-" dados não disponíveis. Veja discussão a respeito desses dados na seção 2 deste artigo e, para maiores informações, Barros (2011, Apêndice estatístico). 
Tabela A-2 - Coeficiente de importação de ferro e aço no Brasil, 1901-1940

\begin{tabular}{|c|c|c|c|c|c|c|c|c|}
\hline & \multicolumn{2}{|c|}{ Ferro-gusa } & \multicolumn{2}{|c|}{ Aço } & \multicolumn{2}{|c|}{ Laminados } & \multicolumn{2}{|c|}{ Total ferro e aço } \\
\hline & quant. (\%) & valor (\%) & quant. (\%) & valor (\%) & quant. (\%) & valor (\%) & quant. (\%) & valor (\%) \\
\hline 1901 & 71,7 & 78,4 & 100,0 & 100,0 & 100,0 & 100,0 & 98,7 & 99,6 \\
\hline 1902 & 70,3 & 77,2 & 100,0 & 100,0 & 100,0 & 100,0 & 98,7 & 99,6 \\
\hline 1903 & 70,4 & 77,3 & 100,0 & 100,0 & 100,0 & 100,0 & 98,6 & 99,6 \\
\hline 1904 & 70,9 & 77,7 & 100,0 & 100,0 & 100,0 & 100,0 & 98,5 & 99,6 \\
\hline 1905 & 76,4 & 82,2 & 100,0 & 100,0 & 100,0 & 100,0 & 99,0 & 99,7 \\
\hline 1906 & 85,6 & 89,5 & 100,0 & 100,0 & 100,0 & 100,0 & 99,1 & 99,7 \\
\hline 1907 & 83,3 & 87,7 & 100,0 & 100,0 & 100,0 & 100,0 & 99,3 & 99,8 \\
\hline 1908 & 81,0 & 85,9 & 100,0 & 100,0 & 100,0 & 100,0 & 99,2 & 99,7 \\
\hline 1909 & 82,5 & 87,1 & 100,0 & 100,0 & 100,0 & 100,0 & 99,3 & 99,8 \\
\hline 1910 & 82,1 & 86,8 & 100,0 & 100,0 & 100,0 & 100,0 & 99,2 & 99,7 \\
\hline 1911 & 83,4 & 87,8 & 100,0 & 100,0 & 100,0 & 100,0 & 99,0 & 99,7 \\
\hline 1912 & 80,0 & 85,1 & 100,0 & 100,0 & 100,0 & 100,0 & 99,2 & 99,7 \\
\hline 1913 & 83,1 & 87,5 & 100,0 & 100,0 & 100,0 & 100,0 & 99,2 & 99,7 \\
\hline 1914 & 68,7 & 75,8 & 100,0 & 100,0 & 100,0 & 100,0 & 98,8 & 99,6 \\
\hline 1915 & 41,7 & 50,6 & 100,0 & 100,0 & 100,0 & 100,0 & 96,3 & 98,9 \\
\hline 1916 & 36,2 & 44,7 & 100,0 & 100,0 & 100,0 & 100,0 & 95,4 & 98,9 \\
\hline 1917 & 17,1 & 22,7 & 100,0 & 100,0 & 100,0 & 100,0 & 91,1 & 97,7 \\
\hline 1918 & 1,9 & 2,7 & 100,0 & 100,0 & 100,0 & 100,0 & 78,9 & 91,3 \\
\hline 1919 & 20,3 & 24,2 & 100,0 & 100,0 & 100,0 & 100,0 & 92,9 & 97,4 \\
\hline 1920 & 32,9 & 44,8 & 98,8 & 95,3 & 100,0 & 100,0 & 94,8 & 97,4 \\
\hline 1921 & 5,8 & 11,1 & 100,0 & 100,0 & 100,0 & 100,0 & 91,4 & 97,4 \\
\hline 1922 & 14,7 & 16,3 & 100,0 & 100,0 & 100,0 & 100,0 & 91,2 & 96,3 \\
\hline 1923 & 17,3 & 28,4 & 100,0 & 100,0 & 100,0 & 100,0 & 88,7 & 96,9 \\
\hline 1924 & 39,7 & 49,4 & 92,6 & 93,7 & 98,1 & 98,0 & 90,5 & 95,4 \\
\hline 1925 & 28,1 & 30,9 & 86,6 & 86,6 & 99,9 & 99,9 & 90,2 & 94,9 \\
\hline 1926 & 43,3 & 36,7 & 86,2 & 80,6 & 95,4 & 92,9 & 88,7 & 88,4 \\
\hline 1927 & 40,2 & 47,2 & 90,0 & 86,8 & 94,9 & 93,7 & 90,6 & 91,3 \\
\hline 1928 & 10,6 & 14,8 & 75,7 & 70,2 & 92,8 & 90,7 & 84,8 & 85,5 \\
\hline 1929 & 12,6 & 15,7 & 74,5 & 68,9 & 90,7 & 88,4 & 80,6 & 82,2 \\
\hline 1930 & 5,5 & 7,5 & 56,9 & 52,7 & 86,9 & 84,6 & 71,0 & 75,6 \\
\hline 1931 & 2,2 & 6,2 & 23,8 & 31,6 & 78,3 & 80,2 & 55,7 & 69,0 \\
\hline 1932 & 2,1 & 4,4 & 18,7 & 23,4 & 71,1 & 70,0 & 47,6 & 56,6 \\
\hline 1933 & 2,6 & 5,4 & 31,9 & 36,4 & 82,0 & 80,8 & 60,5 & 69,2 \\
\hline 1934 & 1,3 & 3,6 & 40,2 & 53,2 & 82,3 & 82,6 & 61,4 & 73,4 \\
\hline 1935 & 0,8 & 3,9 & 36,5 & 57,4 & 81,7 & 87,8 & 59,8 & 80,0 \\
\hline 1936 & 1,6 & 4,1 & 35,1 & 47,4 & 80,2 & 84,0 & 57,9 & 73,7 \\
\hline 1937 & 1,3 & 4,3 & 41,3 & 55,7 & 82,9 & 86,8 & 62,1 & 77,6 \\
\hline 1938 & 0,8 & 3,6 & 28,1 & 44,7 & 71,3 & 78,5 & 45,4 & 65,9 \\
\hline 1939 & 0,3 & 3,1 & 16,2 & 27,8 & 73,8 & 79,9 & 45,0 & 64,9 \\
\hline 1940 & 0,3 & 2,0 & 12,0 & 25,1 & 65,5 & 76,1 & 37,4 & 61,4 \\
\hline
\end{tabular}

Fontes: Barros (2011: 219-20).

Observações: O coeficiente de importações foi definido como importações sobre consumo aparente, e foi calculado tanto para quantidade quanto para valor. O consumo aparente utilizado para esta estimativa foi definindo como a soma da produção doméstica e das importações, ou seja, supusemos que as exportações são nulas, o que não é totalmente verdadeiro, mas constitui muito boa aproximação para o caso em questão. Para maiores informações sobre as fontes e descrição detalhada dos dados veja Barros (2011, Apêndice estatístico). 
Tabela A-3 - Índice do valor da produção siderúrgica a valores constantes, 19011940

\begin{tabular}{|c|c|c|c|}
\hline Ano & $\begin{array}{l}\text { Índice do valor da produção } \\
\text { siderúrgica }(1901=100)\end{array}$ & Ano & $\begin{array}{l}\text { Índice do valor da produção } \\
\text { siderúrgica }(1901=100)\end{array}$ \\
\hline 1901 & 100 & 1921 & 2.122 \\
\hline 1902 & 152 & 1922 & 2.154 \\
\hline 1903 & 165 & 1923 & 3.051 \\
\hline 1904 & 207 & 1924 & 5.129 \\
\hline 1905 & 169 & 1925 & 5.563 \\
\hline 1906 & 200 & 1926 & 6.442 \\
\hline 1907 & 230 & 1927 & 5.935 \\
\hline 1908 & 226 & 1928 & 10.497 \\
\hline 1909 & 259 & 1929 & 13.468 \\
\hline 1910 & 322 & 1930 & 11.735 \\
\hline 1911 & 395 & 1931 & 13.759 \\
\hline 1912 & 420 & 1932 & 19.329 \\
\hline 1913 & 485 & 1933 & 21.104 \\
\hline 1914 & 264 & 1934 & 24.435 \\
\hline 1915 & 395 & 1935 & 26.803 \\
\hline 1916 & 517 & 1936 & 32.094 \\
\hline 1917 & 926 & 1937 & 35.178 \\
\hline 1918 & 1.423 & 1938 & 41.267 \\
\hline 1919 & 1.309 & 1939 & 51.805 \\
\hline 1920 & 1.873 & 1940 & 64.502 \\
\hline
\end{tabular}

Fonte: Barros (2011: 223).

Observações: A estimativa deste índice do valor da produção siderúrgica doméstica foi feita contemplando o consumo intermediário de produtos siderúrgicos pelo próprio setor siderúrgico, vale dizer, este índice procura captar o valor da produção siderúrgica destinado a outros setores da economia. Para a estimativa não utilizamos um deflator previamente disponível, mas fizemos uso de algumas características do comportamento dos preços do próprio setor e de informações de que dispúnhamos a respeito. O índice é uma agregação das quantidades produzidas pelo setor ponderada pelos preços relativos do próprio setor. Trata-se, portanto, de um índice a valores constantes no sentido de que o valor de $1 \mathrm{t}$ de ferro-gusa em 1901 = o valor $1 \mathrm{t}$ de ferro-gusa em 1940. As produções dos demais produtos (aço e laminados) foram agregados aos valores da produção siderúrgica ponderadas pelos seus preços médios relativos aos do ferro gusa para cada ano. Para avaliar a robustez dessa estimativa, foi gerada uma série comparável a essa a partir do valor da produção do setor, deflacionado pelo deflator implícito do setor industrial (IBGE, 1990: 177). Há um bom grau de consistência entre os índices no período entre 1919 e 1936 (a disponibilidade de dados do valor da produção vai só até esse ano), e especialmente entre 1919 e 1931. Para maiores informações sobre as fontes e sobre a estimativa veja Barros (2011, Apêndice estatístico). 